\title{
Niche Analysis and Conservation of Bird Species Using Urban Core Areas
}

\author{
Vasilios Liordos ${ }^{1, * \mathbb{C}}$, Jukka Jokimäki ${ }^{2}{ }^{\mathbb{D}}$, Marja-Liisa Kaisanlahti-Jokimäki ${ }^{2}$, Evangelos Valsamidis ${ }^{1}$ \\ and Vasileios J. Kontsiotis ${ }^{1}$
}

1 Department of Forest and Natural Environment Sciences, International Hellenic University, 66100 Drama, Greece; vagvals@yahoo.gr (E.V.); kontsiotisv@yahoo.gr (V.J.K.)

2 Arctic Centre, University of Lapland, 96101 Rovaniemi, Finland; jukka.jokimaki@ulapland.fi (J.J.); marja-liisa.kaisanlahti@ulapland.fi (M.-L.K.-J.)

* Correspondence: liordos@for.ihu.gr

check for updates

Citation: Liordos, V.; Jokimäki, J.; Kaisanlahti-Jokimäki, M.-L.; Valsamidis, E.; Kontsiotis, V.J. Niche Analysis and Conservation of Bird Species Using Urban Core Areas. Sustainability 2021, 13, 6327. https:// doi.org/10.3390/su13116327

Academic Editor: Richard A. Loyn

Received: 25 April 2021

Accepted: 1 June 2021

Published: 2 June 2021

Publisher's Note: MDPI stays neutral with regard to jurisdictional claims in published maps and institutional affiliations.

Copyright: (c) 2021 by the authors. Licensee MDPI, Basel, Switzerland. This article is an open access article distributed under the terms and conditions of the Creative Commons Attribution (CC BY) license (https:/ / creativecommons.org/licenses/by/ $4.0 /)$.

\begin{abstract}
Knowing the ecological requirements of bird species is essential for their successful conservation. We studied the niche characteristics of birds in managed small-sized green spaces in the urban core areas of southern (Kavala, Greece) and northern Europe (Rovaniemi, Finland), during the breeding season, based on a set of 16 environmental variables and using Outlying Mean Index, a multivariate ordination technique. Overall, 26 bird species in Kavala and 15 in Rovaniemi were recorded in more than $5 \%$ of the green spaces and were used in detailed analyses. In both areas, bird species occupied different niches of varying marginality and breadth, indicating varying responses to urban environmental conditions. Birds showed high specialization in niche position, with 12 species in Kavala (46.2\%) and six species in Rovaniemi (40.0\%) having marginal niches. Niche breadth was narrower in Rovaniemi than in Kavala. Species in both communities were more strongly associated either with large green spaces located further away from the city center and having a high vegetation cover (urban adapters; e.g., Common Chaffinch (Fringilla coelebs), European Greenfinch (Chloris chloris), Eurasian Blue Tit (Cyanistes caeruleus)) or with green spaces located closer to the city center and having high gray area cover and anthropogenic disturbance level (urban exploiters; e.g., Western Jackdaw (Corvus monedula), House Sparrow (Passer domesticus), Eurasian Magpie (Pica pica)). The eleven species that were common to both study areas similarly used the environmental variables and had similar niches, indicating that birds respond similarly to urbanization irrespective of latitude. Sixteen species in Kavala and eleven species in Rovaniemi were identified as conservation priority species, based on their niche specialization level and conservation status. The management actions proposed for the conservation of priority species will also benefit other species with similar ecological requirements and ultimately help maintain diverse bird communities in small-sized green spaces in urban core areas.
\end{abstract}

Keywords: generalists; specialists; niche breadth; marginality; urban core areas; small green spaces; Mediterranean; Fennoscandia

\section{Introduction}

Hutchinson's [1] concept of the realized niche refers to the range of environmental conditions in which a species can survive, grow, reproduce and maintain a viable population, even in the presence of competitors and predators. Hutchinson [1] and Whittaker et al. [2] defined the ecological niche as an $n$-dimensional hypervolume (with ' $n$ ' being the number of environmental conditions examined) that determines species distribution. According to niche theory, species can be assigned along a narrow-broad niche continuum, from specialists that use a narrow range of environmental conditions to generalists that use a broad range of environmental conditions.

Birds are important components of urban landscapes, promoting ecosystem health [3]. They are also good indicators of the diversity of other animal groups and of habitat 
condition $[4,5]$ because they are conspicuous, easy to quantify and quickly respond to habitat changes caused by urbanization [6,7]. The maintenance of a diverse bird community in cities provides important ecosystem services, such as pest control [8], plant pollination [9], art inspiration [10] and improvement of human well-being by increasing vitality and happiness and reducing stress and anxiety in urban residents [11,12]. Furthermore, the importance of urban green spaces has greatly increased during the COVID-19 pandemic. Birdwatchers from 97 countries reported that they primarily visit local small urban green spaces due to strict lockdown regulations [13]. However, birds face novel conditions in cities, mostly due to the destruction and fragmentation of natural habitats, especially forests, which are replaced by open habitats and impervious surfaces [14]. Moreover, birds in cities are generally more susceptible to predation, by both natural (e.g., corvids, hawks) and domestic (e.g., cats, dogs) predators [15,16], and disease due to anthropogenic pollution (e.g., organic, air, noise $[17,18])$. Such novel conditions induced by urbanization act as ecological filters, altering bird species distribution and community composition along the urbanization gradient [19-23]. Birds that occupy urban habitats are usually either exploiters-which often utilize human subsidized resources, such as artificial nesting and feeding sites as well as food waste, and their abundance is usually not dependent on vegetation-or adapters, which require considerable vegetation for shelter and food and utilize fewer anthropogenic resources [24,25].

Urban green spaces act as island habitats, hosting diverse and abundant bird communities $[26,27]$. In addition, urban areas are locally important for the conservation of birds, as they host many threatened species because they often occupy biodiversity hotspots $[28,29]$. As urban birds and their habitats also have great social and educational value, conservation efforts should increase in areas where people live and work [30]. Knowing the ecological requirements of bird species and their degree of specialization is essential for setting conservation priorities that would allow for successful conservation management for maintaining diverse urban bird communities.

Environmental variables might vary and differently affect bird species distribution, between green spaces located in urban core areas that are usually intensively managed, small-sized and heavily used by local residents, and green spaces located at the periphery of cities that are usually less managed, larger in size and less visited by people [31,32]. However, managed, small-sized green spaces in urban core areas have received relatively little attention, although they host diverse and important bird communities (e.g., [33-37]). In addition, environmental variables at the local scale are often more important than regional ones in determining species distribution and community composition in urban landscapes [38-41]. Such variables include patch level variables (e.g., green space size, amount of gray, tree, shrub and bare ground cover [6,26,35,42]), matrix level variables (e.g., distance from the city edge and center, building height $[37,43,44])$ and disturbance variables (e.g., anthropogenic noise, pedestrian and car traffic [45-47]).

Earlier studies considered the species richness, diversity and organization of urban bird communities at various spatial scales (e.g., [7,22,23,48-50]). Measures of niche characteristics have been mostly used to explain why some species adapt to the novel urban conditions while others do not, generally comparing species' ecological requirements with habitat conditions in cities and in natural habitats [51-55]. Studies comparing the niches of bird species in urban core areas are lacking. We used niche theory concepts to describe, at the local scale, the structure and niche characteristics of the bird communities in two similar-sized European cities, Kavala (Greece) in southern Europe and Rovaniemi (Finland) in northern Europe. We described species niches using niche position, marginality and breadth. Niche position shows how typical the environmental conditions used by a species are relative to those that are available in the region [56]. Niche position is measured by niche marginality: species with marginal niches use atypical or uncommon conditions within a region and species with non-marginal niches use typical or common conditions within a region. Niche breadth measures a species' tolerance to contrasting environmental conditions. Low species tolerance means use of a limited range of environmental conditions 
(specialist species), while high tolerance means the use of a wide range of environmental conditions (generalist species). Such measures can be used to identify the degree of specialization of bird species breeding in urban core areas and as such they could have important implications for their conservation management. Many studies have found that niche position is a strong predictor of ecological patterns and proposed that it can be a better predictor of specialization than niche breadth [53,57-60]).

We measured the abundance of breeding bird species and local environmental variables to describe the distribution and niche characteristics of urban bird species at managed small-sized green spaces located in the most urbanized core areas of Kavala and Rovaniemi. We also set conservation priorities, depending on niche specialization and conservation status, and proposed suitable management actions. We predicted that (1) niche characteristics will differ between different species, (2) environmental variables will varyingly influence species distribution, allowing for their classification either as adapters or as exploiters, (3) species with similar niche characteristics will be similarly influenced by environmental variables in both bird communities irrespective of the latitudinal location and (4) both bird communities will be important for conservation of priority species.

\section{Materials and Methods}

\subsection{Study Area}

The study was carried out in Kavala, Greece $\left(40^{\circ} 56^{\prime} \mathrm{N}, 24^{\circ} 24^{\prime} \mathrm{E}\right)$, located in southern Europe, and Rovaniemi, Finland $\left(66^{\circ} 30^{\prime} \mathrm{N}, 25^{\circ} 44^{\prime} \mathrm{E}\right)$, located in northern Europe, in their most urbanized core areas, i.e., the central part of the municipality that is covered by more than 50\% impervious surface area, containing large buildings, primarily stores, offices and dense residential areas (Figure 1). In these areas, all the green spaces are man-made and managed and anthropogenic impacts on birds are supposed to be maximal.

The Kavala municipality has 70,501 inhabitants [61], covering approximately $351.35 \mathrm{~km}^{2}$. Field work was performed in the core urban area of Kavala, were most inhabitants of the municipality live (56,371 [61]). It covers approximately $8.0 \mathrm{~km}^{2}$ (about 7050 inhabitants $/ \mathrm{km}^{2}$ ) and is delimited by the sea to the south and by a Turkish Pine (Pinus brutia) dominated peri-urban forest to the north. Two Turkish Pine-dominated woodlands, the Panagiouda (17.0 ha) to the west and the Pentakosion (1.3 ha) to the east, are among the most important green spaces of Kavala. However, the most common green spaces are small square gardens ( $<3 \mathrm{ha}$ ), which are dispersed throughout the city and are usually partly covered by planted trees and shrubs, and gray infrastructure such as paved walks, playgrounds, cafés and restaurants.

Rovaniemi municipality has 63,631 inhabitants [62], covering approximately $8016 \mathrm{~km}^{2}$ (7601 km² by land). It is located near the Arctic Circle and daylight duration is very high in summer since the sun does not set between 7 June and 6 July. Forests (61.4\%) and mires with trees $(25.1 \%)$ cover most of the land. The proportion of urban areas of the municipality is only about $0.3 \%$ of the land area. Most of the inhabitants $(50,000$; about 4000 inhabitants $/ \mathrm{km}^{2}$ ) of the municipality live in the core city area, where the field work was performed. Although the forests surrounding the city are pine-dominated (Scots Pine (Pinus sylvestris)), deciduous trees (e.g., Silver Birch (Betula pendula), Rowan (Sorbus aucuparia)) are favored in urban park planning.

\subsection{Bird Surveys}

We selected 19 green spaces from each city, representing all available managed green spaces in the core areas of both cities, and established one survey station at the center of each green space. Green spaces and their corresponding survey stations were located at least $250 \mathrm{~m}$ apart to avoid the double counting of individuals. The single-visit fixed-radius $(\leq 50 \mathrm{~m})$ point count method was employed to assess the abundance and diversity of bird species [63]. Birds were surveyed very early in the morning, during the period of maximum bird activity. All surveys were conducted before $1030 \mathrm{~h}$. They were conducted following the recommendations of Bibby et al. [63], with a 5 min silent period before starting the 
5 min bird surveys. Surveys were conducted during fine weather by the same observer (E.V. in Kavala, J.J. in Rovaniemi) to avoid introducing an observer effect. Counts were carried out during the peak breeding season, 9-13 May 2016 in Kavala and 1-15 June 2020 in Rovaniemi.

The use of point counts is appropriate in urban areas due to built-up structures $[39,64]$. Several studies have validated the efficiency of single-year, single-visit studies $[27,39,65]$. Species were assumed to have similar detection probabilities because we kept the sampling radius relatively small $(50 \mathrm{~m})$; sampling points were located in similar habitats and vegetation cover was relatively low. This assumption is common to studies of urban bird communities [66-69]. Moreover, van Heezik and Seddon [64] reported that standardized, nondetectability-based point counts could provide useful information on the structure and relative abundance of bird communities in urban areas. Therefore, the use of the same methodology allowed for valid comparisons between the two study areas.

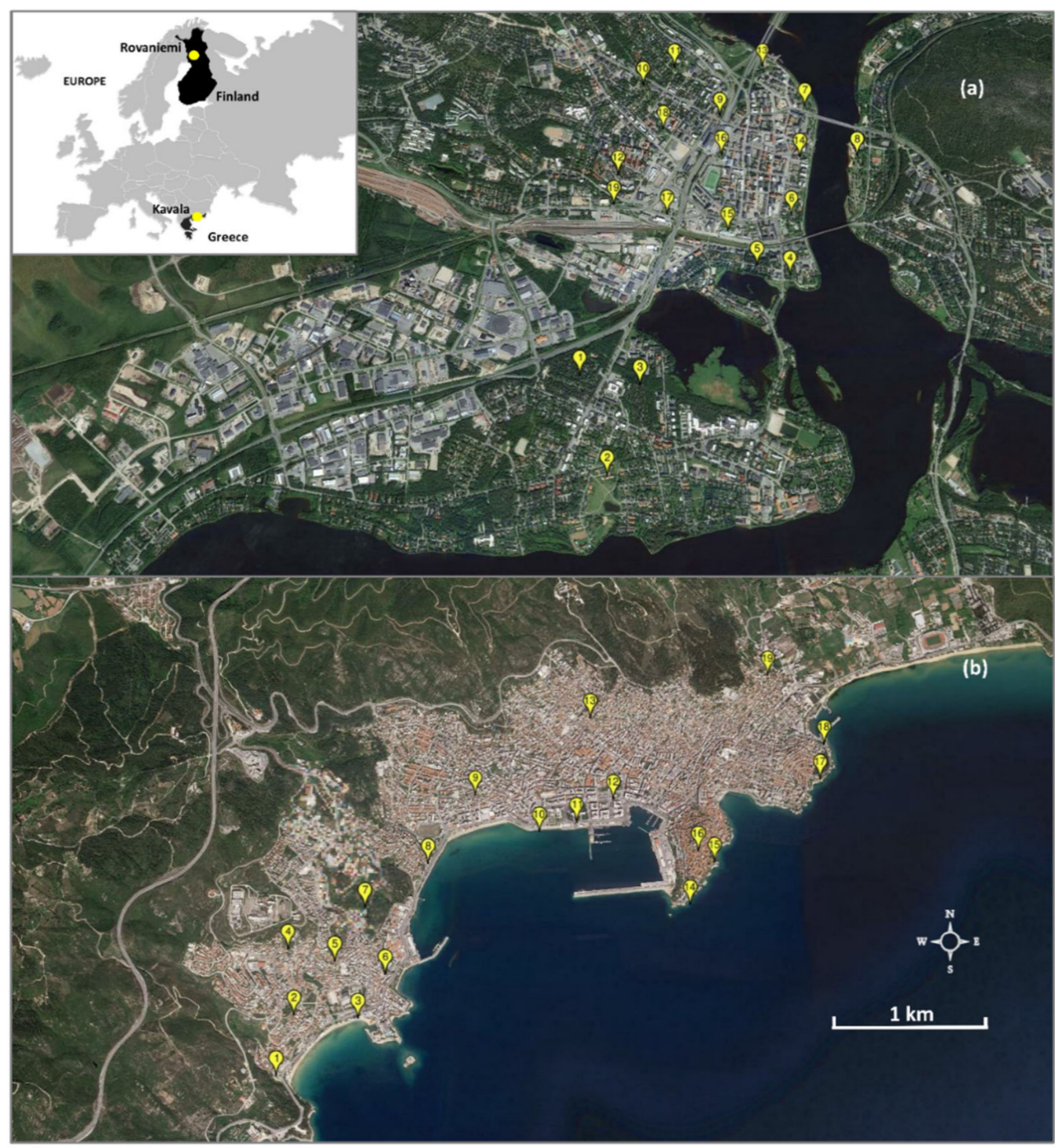

Figure 1. Maps of (a) Rovaniemi, Finland, and (b) Kavala, Greece, showing the location of the survey stations $(n=19)$. Scale applies to both maps. Main map: Google Earth; Image Landsat/Copernicus, Data SIO, NOAA, U.S. Navy, NGA, GEBCO; @2020 Google, Image@2021 TerraMetrics, Image@2021 Maxar Technologies. Inset map: GinkgoMaps. 
The presence of every individual bird as well as any indication of breeding activity within the survey station was noted (singing males, territorial behavior, nest construction or provisioning, occupied nests, etc.). This method is not appropriate for the assessment of the abundance of raptors, aerial feeders and crepuscular species [63], and therefore such species were not used in our analyses, with the exception of the Northern House Martin (Delichon urbica) and the Barn Swallow (Hirundo rustica) in Kavala and the Common Swift (Apus apus) and the Sand Martin (Riparia riparia) in Rovaniemi. These species are important features of the urban landscape and were counted only when involved in direct breeding activities (e.g., entering into the nest hole) within the $50 \mathrm{~m}$ survey point radius.

At the European level, species conservation status was taken from [70]. At the national level, conservation status was taken from the 2019 Red List of Finnish Species [71] and the Red Data Book of Threatened Animals of Greece [72]. (See species classification in Table S1.)

\subsection{Environmental Variables}

Sixteen environmental variables were measured in both cities to test their effect on bird abundance and diversity (Table S2). Distance of the center of each green space from the city center and city edge $(\mathrm{km})$, green space size (ha), perimeter (edge) length $(\mathrm{km})$ and relative edge length, calculated as perimeter divided by area $\left(\mathrm{km} / \mathrm{km}^{2}\right)$, were measured from aerial maps. Land cover was measured in the field as the percentage of tree, shrub, bare ground and impervious (gray cover) surface within a radius of $50 \mathrm{~m}$ of every survey station. Tree cover was estimated separately for the coniferous and deciduous trees. Mean noise levels (dBA) were measured twice at each survey station, in the morning (just before the initial bird survey started), before daily traffic starts, and at midday, when daily traffic is at its maximum. Noise measurements were recorded for $5 \mathrm{~min}$ during each session (76 sessions in total), by using a portable noise meter in Kavala (Model Nova 42, Pulsar Instruments ${ }^{\mathrm{TM}}$ ) and an environmental multimeter in Rovaniemi (MASTECH ${ }^{\circledR} \mathrm{MS6300}$ Environment Multimeter), directed towards the nearest road at the breast height. Car traffic (number of cars per minute) and pedestrian traffic (number of people per minute) were also recorded within a radius of $50 \mathrm{~m}$ of every survey station during a $5 \mathrm{~min}$ period before the initial bird surveys started. We used the number of floors of the buildings surrounding each green space as an index of the matrix type. The number of floors was calculated from the four main compass directions in the field, and the average value was used later in analyses.

Although Kavala is more densely populated than Rovaniemi, green space size (Kavala, mean $1.5 \pm 3.8$ (SD) ha, range 0.1-17.0 ha; Rovaniemi, $1.7 \pm 1.9$ ha, 0.1-8.5 ha; MannWhitney U-test $z=2.410, p=0.063$ after Bonferroni correction) and matrix type indices such as distance of green spaces from the city center (Kavala, $1.5 \pm 0.9 \mathrm{~km}, 0.1-3.1 \mathrm{~km}$; Rovaniemi, $0.9 \pm 0.7 \mathrm{~km}, 0.3-2.6 \mathrm{~km} ; z=-2.015, p=0.075$ ) and number of floors (Kavala, $2.9 \pm 1.6,1-6 ;$ Rovaniemi, $2.6 \pm 1.2,1-4 ; z=0.150, p=0.998)$ did not significantly differ between the cities, suggesting that green spaces could be compared.

\subsection{Data Analysis}

The Outlying Mean Index (hereafter OMI) analysis [73], a two-table ordination technique, was used to explore the influence of environmental variables on the bird communities of Kavala and Rovaniemi. The first table included 26 species for the Kavala and 15 species for the Rovaniemi dataset (after excluding species occurring in $<5 \%$ of all counts; see Table S1). The second table included the 16 environmental variables measured in both cities (see Table S2). In contrast to other multivariate methods, OMI analysis gives equal weight to species-rich and species-poor sites, makes no assumption about the shape of species response curves to the environmental gradients (linear or unimodal) and its interpretations are robust to multicollinearity among the environmental variables [73]. The OMI analysis provides an inertia estimate representing the total variance of the environmental table weighted by the species distribution profile. This variability is decomposed into three 
niche parameters, namely OMI, tolerance and residual tolerance (expressed as percentages of inertia). OMI measures the marginality of species, or the distance between the average environmental conditions used by a species and the mean environmental conditions of the sampling units of the study area. A high marginality indicates that a species is found under atypical environmental conditions within the study area, whereas a low marginality indicates that there is no difference between the overall environmental conditions and those where the species is found. Tolerance is a measure of niche breadth. High tolerance values indicate that the species is distributed along a variety of environmental conditions (generalist species), while low values imply that the species is distributed along a more limited range of environmental conditions (specialist species). Residual tolerance indicates the variance in species niche not considered. Niche parameters were estimated with the function niche of the ade4 R package [74]. The statistical significance of the marginality of each species was tested by a Monte Carlo random permutation test with 10,000 permutations, applying the Holm correction for multiple testing. Pearson's correlation coefficients between the environmental variables and OMI axes were computed with the rcorr function of the Hmisc R package [75].

We classified species in conservation priority categories depending on niche specialization and conservation status. Species that were both specialized and threatened at the European or national levels were classified as first conservation priority. Species that were either specialized or threatened at the European or national levels were classified as second conservation priority.

All statistical analyses were performed in program $\mathrm{R}$ 4.0.2 [76].

\section{Results}

\subsection{Niche Analysis for the Breeding Bird Community of Kavala}

OMI analysis retained the first two axes, which accounted for $79.83 \%$ of the total inertia (axis 1: 56.34\%; axis 2: $23.49 \%$ ). OMI values varied greatly, ranging from $1.80 \%$ (Northern House Martin) to $87.20 \%$ of inertia (Eurasian Tree Sparrow (Passer montanus)) (Table 1, Figure 2a). Analysis showed that 12 of 26 species examined (46.2\%) showed significant deviation from the mean habitat condition, indicating marginal niches. The remaining 14 species (53.8\%) had low OMI index values, indicating non-marginal niches, typical of the local average urban niche. Moreover, the average marginality of all species, the criterion optimized by OMI analysis, was significantly different from the mean habitat condition $(p<0.001)$. Tolerance values revealed species occupying narrow niches (tolerance $<20 \%$ of inertia) and species with broader niches (tolerance $>30 \%$ of inertia). However, the generally high residual tolerance, ranging from $22.20 \%$ to $81.30 \%$ of inertia, indicated that additional important factors that affect species distribution and resource use should be considered.

The first OMI axis was significantly positively correlated with tree cover, coniferous tree cover, green space size and perimeter, and significantly negatively correlated with morning and midday noise levels, car and pedestrian traffic, gray cover and building height (Table 2, Figure 2c). The second OMI axis was significantly positively correlated with gray cover and relative edge length and significantly negatively correlated with car and pedestrian traffic, green space size and perimeter, tree cover and coniferous tree cover. A large group of species was positively correlated with the first axis and negatively correlated with the second axis, species characteristic of green spaces with higher tree cover and coniferous tree cover and larger size and perimeter (Figure 2a,c; Common Cuckoo (Cuculus canorus), European Bee-eater (Merops apiaster), Syrian Woodpecker (Dendrocopos syriacus), Eurasian Blackbird (Turdus merula), Sardinian Warbler (Sylvia melanocephala), Willow Warbler (Phylloscopus trochilus), Common Nightingale (Luscinia megarhynchos), Great Tit (Parus major), Eurasian Blue Tit (Cyanistes caeruleus), Eurasian Jay (Garrulus glandarius), Common Chaffinch (Fringilla coelebs), European Greenfinch (Chloris chloris), European Serin (Serinus serinus)). The Feral Pigeon (Columba livia), Collared Dove (Streptopelia decaocto), Northern House Martin, Eurasian Magpie (Pica pica), Western Jackdaw (Corvus monedula), 
Hooded Crow (Corvus cornix), Common Starling (Sturnus vulgaris) and European Goldfinch (Carduelis carduelis) formed a group of species generally negatively correlated with both axes, being common in green spaces with high disturbance (noise and traffic load), surrounded by high buildings. The Eurasian Tree Sparrow was the species most positively correlated with the second axis, preferring edge habitats with generally high gray and bare ground cover.

Table 1. Niche parameters of the bird species of Kavala and Rovaniemi. Inertia: total variability; OMI: outlying mean index or marginality (\%); T: tolerance index (\%), RT: residual tolerance index (\%).

\begin{tabular}{|c|c|c|c|c|c|c|c|c|c|}
\hline \multirow{2}{*}{ Species Name } & \multirow{2}{*}{ Species Code } & \multicolumn{4}{|c|}{ Kavala } & \multicolumn{4}{|c|}{ Rovaniemi } \\
\hline & & Inertia & OMI (\%) & $\mathrm{T}(\%)$ & RT (\%) & Inertia & OMI (\%) & $\mathrm{T}(\%)$ & RT (\%) \\
\hline Black-headed Gull & Chrrid & - & - & - & - & 12.1 & 79.0 & 3.9 & 17.1 \\
\hline Feral Pigeon & Colliv & 23.6 & $37.0 *$ & 36.4 & 26.6 & - & - & - & - \\
\hline Collared Dove & Strdec & 15.1 & 5.3 & 24.8 & 69.9 & - & - & - & - \\
\hline Common Cuckoo & Cuccan & 27.8 & $41.8 *$ & 31.7 & 26.6 & - & - & - & - \\
\hline European Bee-eater & Merapi & 40.1 & $47.0 *$ & 21.3 & 31.7 & - & - & - & - \\
\hline Syrian Woodpecker & Densyr & 32.8 & $39.5 *$ & 29.1 & 31.3 & - & - & - & - \\
\hline $\begin{array}{l}\text { Northern House } \\
\text { Martin }\end{array}$ & Delurb & 16.1 & 1.8 & 23.9 & 74.3 & - & - & - & - \\
\hline Barn Swallow & Hirrus & 9.6 & 9.2 & 9.5 & 81.3 & - & - & - & - \\
\hline White Wagtail & Motalb & 10.9 & 42.7 & 0.7 & 56.6 & 16.8 & 6.8 & 10.3 & 82.9 \\
\hline Eurasian Blackbird & Turmer & 28.6 & $39.5 *$ & 33.0 & 27.5 & - & - & - & - \\
\hline Fieldfare & Turpil & - & - & - & - & 15.5 & 10.8 & 22.4 & 66.8 \\
\hline Sardinian Warbler & Sylmel & 23.1 & 29.4 & 25.4 & 45.2 & - & - & - & - \\
\hline Willow Warbler & Phytro & 32.6 & $45.0 *$ & 30.4 & 24.7 & 19.7 & 15.3 & 15.8 & 68.9 \\
\hline Olivaceous Warbler & Idupal & 14.9 & 25.1 & 0.0 & 74.9 & - & - & - & - \\
\hline $\begin{array}{l}\text { Common } \\
\text { Nightingale }\end{array}$ & Lusmeg & 19.1 & 22.6 & 16.1 & 61.4 & - & - & - & - \\
\hline Great Tit & Parmaj & 24.7 & 11.1 & 34.9 & 54.0 & 17.5 & 6.6 & 25.9 & 67.5 \\
\hline Eurasian Blue Tit & Cyacae & 32.6 & $36.2 *$ & 20.6 & 43.2 & 23.1 & $38.0 *$ & 8.0 & 54.1 \\
\hline Eurasian Magpie & Picpic & 13.1 & $58.1 *$ & 5.0 & 36.9 & 25.9 & $64.7^{*}$ & 4.9 & 30.5 \\
\hline Eurasian Jay & Gargla & 34.2 & $41.7 *$ & 33.5 & 24.8 & - & - & - & - \\
\hline Western Jackdaw & Cormon & 17.4 & $33.1 *$ & 14.4 & 52.4 & 19.1 & $43.5^{*}$ & 21.9 & 34.6 \\
\hline Hooded Crow & Corcor & 15.7 & 6.0 & 26.4 & 67.6 & 17.3 & $34.7^{*}$ & 14.6 & 50.7 \\
\hline Common Starling & Stuvul & 13.5 & 21.7 & 17.3 & 61.0 & - & - & - & - \\
\hline House Sparrow & Pasdom & 14.8 & 11.2 & 26.1 & 62.8 & 14.6 & 11.9 & 16.6 & 71.5 \\
\hline $\begin{array}{c}\text { Eurasian Tree } \\
\text { Sparrow }\end{array}$ & Pasmon & 13.8 & $87.2 *$ & 0.3 & 12.5 & 11.9 & 20.9 & 11.4 & 67.7 \\
\hline Common Chaffinch & Fricoe & 22.3 & $20.2 *$ & 33.8 & 46.0 & 16.2 & $22.4^{*}$ & 26.0 & 51.6 \\
\hline European Goldfinch & Carcar & 17.3 & 4.3 & 15.4 & 80.3 & - & - & - & - \\
\hline European Greenfinch & Carchl & 21.2 & 8.9 & 34.2 & 56.9 & 17.0 & $42.2 *$ & 14.1 & 43.6 \\
\hline Redpoll & Acafla & - & - & - & - & 19.5 & 38.4 & 17.9 & 43.6 \\
\hline European Serin & Serser & 21.7 & 60.7 & 17.1 & 22.2 & - & - & - & - \\
\hline Eurasian Siskin & Spispi & - & - & - & - & 12.4 & 12.8 & 4.3 & 82.9 \\
\hline
\end{tabular}

* Significant OMI values (Monte Carlo random tests with 10,000 permutations; $p<0.05$ after Holm correction). 

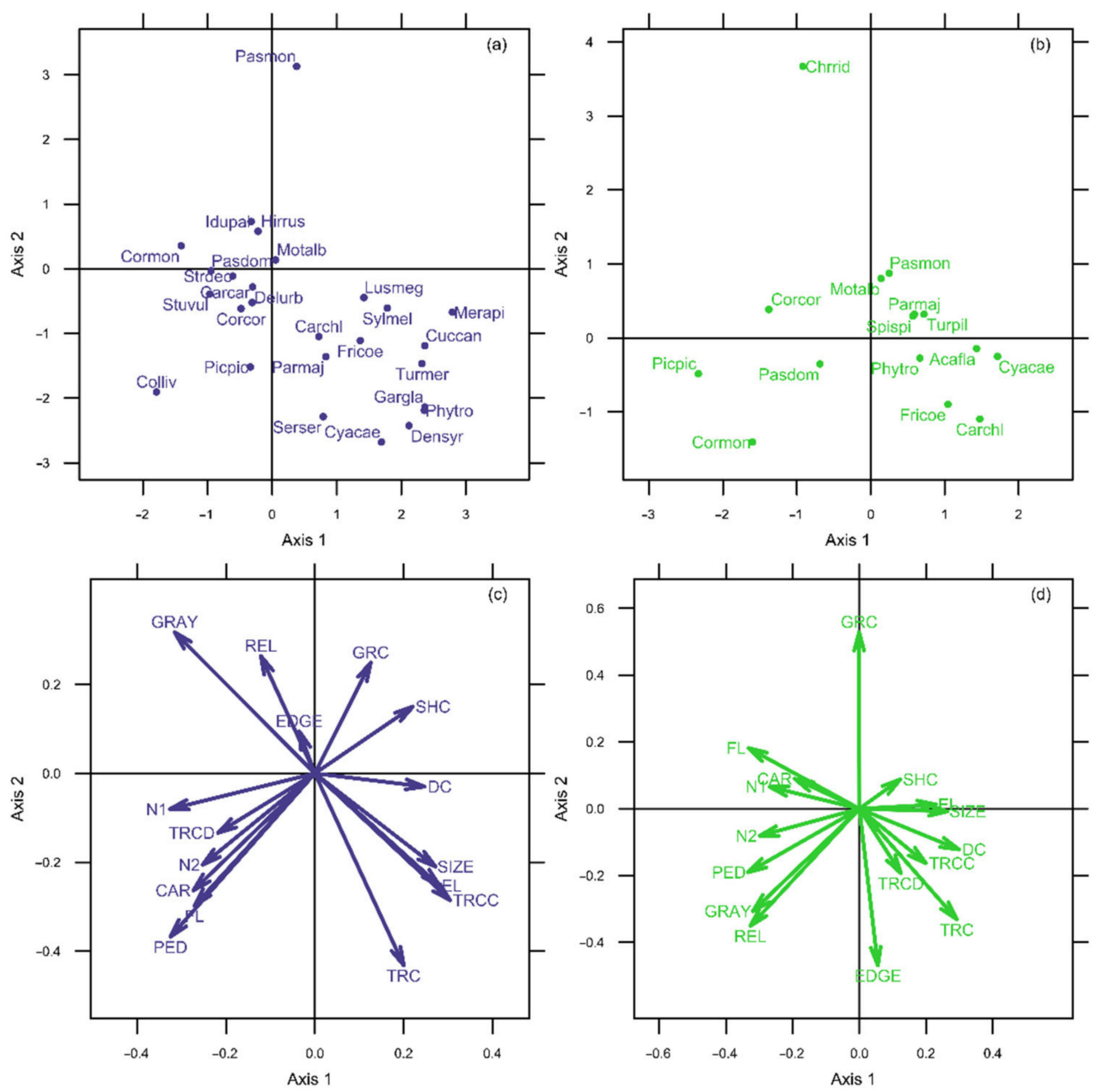

Figure 2. OMI analysis plots for Kavala $(\mathbf{a}, \mathbf{c})$ and Rovaniemi $(\mathbf{b}, \mathbf{d})$ datasets. The origin of the plots represents the mean environmental conditions. Species' position on the factorial plane reveals the degree of difference of their ecological niche to the mean environmental conditions and their correlation with each axis (Kavala, (a); Rovaniemi, (b)). The length of the arrows of environmental variables reflects their relative importance, and the direction of the arrow indicates correlations among variables and with each axis (Kavala, c; Rovaniemi, d). Refer to Table 2 for the species codes and to Table 1 for the environmental variable codes.

\subsection{Niche Analysis for the Breeding Bird Community of Rovaniemi}

OMI analysis also retained the first two axes, which accounted for $82.67 \%$ of the total inertia (axis 1: $70.57 \%$; axis 2: $12.10 \%$ ). OMI values highly varied from $6.60 \%$ (Great Tit) to $79.00 \%$ of inertia (Black-headed Gull (Chroicocephalus ridibundus)) (Table 1, Figure 2b). Analysis showed that 6 of 15 species examined $(40.0 \%)$ showed significant deviation from the mean habitat condition, indicating marginal niches. The remaining nine species $(60.0 \%)$ had low OMI index values, indicating non-marginal niches, typical of the local average urban niche. In addition, the average marginality of all species, the criterion optimized by OMI analysis, was significantly different from the mean habitat condition $(p<0.001)$. The relatively low tolerance values (3.90-26.00\% of inertia) revealed that the 15 species of the Rovaniemi assemblage occupied relatively narrow niches. The considerable residual tolerance values (17.10-82.90\% of inertia) suggested that there are other factors important for explaining species distribution and niche breadth. 
Table 2. Pearson's correlation coefficients of the environmental variables with the first two axes of OMI analysis.

\begin{tabular}{|c|c|c|c|c|c|}
\hline \multirow{2}{*}{ Environmental Variables } & \multirow{2}{*}{ Code } & \multicolumn{2}{|c|}{ Kavala } & \multicolumn{2}{|c|}{ Rovaniemi } \\
\hline & & Axis1 & Axis2 & Axis1 & Axis2 \\
\hline Tree cover $(\%)$ & TRC & 0.538 * & $-0.799^{* * *}$ & 0.554 * & $-0.578^{* *}$ \\
\hline Shrub cover $(\%)$ & $\mathrm{SHC}$ & 0.395 & 0.362 & 0.269 & 0.043 \\
\hline Bare ground cover $(\%)$ & GRC & 0.302 & 0.393 & 0.120 & $0.933^{* * *}$ \\
\hline Gray cover $(\%)$ & GRAY & $-0.783^{* * *}$ & $0.591 * *$ & $-0.754 * * *$ & $-0.509 *$ \\
\hline Deciduous tree cover $(\%)$ & TRCD & -0.437 & -0.275 & 0.252 & -0.323 \\
\hline Coniferous tree cover $(\%)$ & TRCC & $0.726^{* * *}$ & $-0.510 *$ & 0.349 & -0.356 \\
\hline Green space size (ha) & SIZE & $0.696^{* * *}$ & $-0.551 *$ & $0.712 * *$ & 0.069 \\
\hline Green space perimeter $(\mathrm{km})$ & EL & $0.666^{* *}$ & $-0.590 * *$ & $0.658^{* *}$ & 0.221 \\
\hline Relative edge length $\left(\mathrm{km} / \mathrm{km}^{2}\right)$ & REL & -0.369 & $0.617^{* *}$ & $-0.745^{* * *}$ & $-0.538 *$ \\
\hline Distance from city edge $(\mathrm{km})$ & EDGE & 0.045 & 0.062 & 0.035 & $-0.766 * * *$ \\
\hline Distance from city center $(\mathrm{km})$ & $\mathrm{DC}$ & 0.440 & -0.035 & $0.788^{* * *}$ & -0.011 \\
\hline Building height (floors/building) & FL & $-0.576^{* *}$ & -0.366 & $-0.734 * * *$ & 0.077 \\
\hline Morning noise level (dBA) & N1 & $-0.872^{* * *}$ & -0.111 & $-0.688^{* *}$ & 0.029 \\
\hline Midday noise level (dBA) & N2 & $-0.699 * * *$ & -0.417 & $-0.746^{* * *}$ & -0.246 \\
\hline Car traffic (cars/min) & CAR & $-0.679 * * *$ & $-0.492 *$ & $-0.530 *$ & -0.172 \\
\hline Pedestrian traffic (people/min) & PED & $-0.644^{* *}$ & $-0.593^{* *}$ & $-0.727^{* * *}$ & -0.213 \\
\hline
\end{tabular}

The first OMI axis was significantly positively correlated with tree cover, green space size and perimeter and distance from the city center, and significantly negatively correlated with morning and midday noise levels, car and pedestrian traffic, gray cover, relative edge length and building height (Table 2, Figure 2d). The second OMI axis was significantly positively correlated with bare ground cover and significantly negatively correlated with distance from the city edge, tree cover, gray cover and relative edge length. The Fieldfare (Turdus pilaris), Willow Warbler, Great Tit, Eurasian Blue Tit, Common Chaffinch, European Greenfinch, Redpoll (Acanthis flammea) and Eurasian Siskin (Spinus spinus) were positively correlated with the first axis, species characteristic of green spaces with higher tree cover, larger size and perimeter, and further from the city center (Figure 2b,d). The Eurasian Magpie, Western Jackdaw, Hooded Crow and House Sparrow (Passer domesticus) were negatively correlated with the first axis, mostly occupying greenspaces with high noise levels, traffic load, gray cover, relative edge length and building height. The Eurasian Tree Sparrow, White Wagtail (Motacilla alba) and, more strongly, the Black-headed Gull were positively correlated with the second axis, preferring open green spaces.

\subsection{Conservation Status and Priority}

Six species had an unfavorable conservation status within Europe (Table S1). Three were recorded in both cities (Willow Warbler, Eurasian Tree Sparrow, House Sparrow), while the other three were recorded only in Kavala (Northern House Martin, Barn Swallow, Common Starling). At the national level, five species were threatened in Finland: the endangered House Sparrow and European Greenfinch, the vulnerable Black-headed Gull and the near-threatened White Wagtail and Eurasian Magpie. The conservation status of urban bird species recorded in Kavala has not been evaluated by the Red Data Book of Threatened Animals of Greece.

In Kavala, one exploiter (Eurasian Tree Sparrow) and one adapter (Willow Warbler) were the first conservation priority species. In Rovaniemi, one exploiter (Eurasian Magpie) and one adapter (European Greenfinch) were the first conservation priority species.

Most species in both communities were assigned to second conservation priority status. In Kavala, seven exploiters (Northern House Martin, Barn Swallow, Common Starling, House Sparrow, Feral Pigeon, Eurasian Magpie, Western Jackdaw) and seven adapters (Eurasian Jay, Common Chaffinch, Eurasian Blue Tit, Eurasian Blackbird, Common Cuckoo, European Bee-eater, Syrian Woodpecker) were the second conservation priority species. In Rovaniemi, six exploiters (House Sparrow, Eurasian Tree Sparrow, Black-headed Gull, 
White Wagtail, Western Jackdaw, Hooded Crow) and three adapters (Common Chaffinch, Eurasian Blue Tit, Willow Warbler,) were the second conservation priority species.

\section{Discussion}

\subsection{Niche Specialization and Habitat Conditions}

The bird species breeding in Kavala's and Rovaniemi's urban core areas occupied different niches of varying marginality and breadth, indicating varying responses to urban environmental conditions. Birds in both Kavala and Rovaniemi could be broadly assigned to either exploiter or adapter status in relation to their response to local environmental variables $[24,25]$. The high niche marginality observed in urban bird communities might be partially explained by the differential use of resources by exploiters (high use of gray and low of green infrastructure) and adapters (low use of gray and high of green infrastructure) in the studied urban core areas.

Several species were recorded only in one of the two bird communities. The Collared Dove, European Bee-eater, Syrian Woodpecker, Sardinian Warbler, Olivaceous Warbler (Iduna pallida), Common Nightingale, European Goldfinch and European Serin are southernly distributed species that do not breed in Rovaniemi, while species such as the Redpoll do not breed in Greece, and others breed very rarely, mostly in mountainous areas (Fieldfare and Eurasian Siskin) [77]. The Northern House Martin, Barn Swallow and Feral Pigeon were abundant in Kavala, while they were not recorded in the study sites of Rovaniemi despite that they belong in the breeding bird community of the city. Feral Pigeon numbers were recently reduced in Rovaniemi, from several hundreds to several dozen due to viral infection (J. Jokimäki, unpublished data). Martins and swallows are not abundant in Rovaniemi, as 90\% of buildings were destroyed in World War II [78], and modern architecture offers few nesting opportunities, especially where balconies are enclosed with windows in response to cold weather.

Eleven species were common in the urban core areas of Kavala and Rovaniemi, in both behaving either as exploiters, preferring green spaces with high gray cover, anthropogenic disturbance and further from the city limits (e.g., Western Jackdaw, House Sparrow, Eurasian Magpie) or as adapters, preferring larger green spaces with high vegetation cover, further from the city center (e.g., Common Chaffinch, European Greenfinch, Eurasian Blue Tit). Furthermore, four of the six specialists of Rovaniemi were also specialists in Kavala. Although Kavala and Rovaniemi are located in different biogeographical areas, both bird communities showed similar responses to urbanization and especially bird species common to both communities were making similar use of local environmental variables and also showed similar niche specialization. These findings agree with findings from previous studies. Urban adapters seek in cities conditions similar to their natural habitats, while urban exploiters are able to make use of novel conditions, which tend to be similar in cities around the world (e.g., nest sites in buildings, food waste), and thus become abundant [19-22,24,25,49].

\subsection{Conservation Management Implications}

A considerable number of species were threatened at the European or national levels or had specialized niches and were therefore assigned to conservation priority status. Other studies also found that European urban core areas [29] and Australian cities [28] are locally important for threatened bird species. Threatened species that were observed in Kavala and Rovaniemi were also recorded in other European cities, more frequently the Eurasian Tree and House Sparrows, Northern House Martin and Barn Swallow [29]. Our findings also suggested that birds, even exploiter species, might mainly depend on a limited set of critical environmental variables in urban core areas. Potential change in the availability of these environmental variables might render the urban environment inhospitable for certain species. This process could be illustrated with the example of exploiters abundant in Kavala, such as the narrow-niche Northern House Martin and Barn Swallow, which 
have severely declined in Rovaniemi due to changes in habitat conditions and were not recorded during our surveys. Such outcomes emphasize the need for conservation actions.

In both communities, adapters were more abundant in larger green spaces with high vegetation cover, especially tree cover, and low rates of urbanization and disturbance. Most conservation priority adapter species nest in trees (Common Chaffinch, European Greenfinch, Eurasian Jay), in holes in trees (Eurasian Blue Tit, Syrian Woodpecker), in shrubs (Eurasian Blackbird) or in shrubs and on the ground (Willow Warbler). The enlargement of green spaces and the increase in tree and shrub cover would benefit adapter species. Particular attention should be given to the retention of mature trees and dense shrubberies. Both of these elements are often scarce in the urban landscape or removed for aesthetic and safety reasons. However, they are vital for cavity nesters the former and for birds that nest in shrubs or on the ground under shrubs the latter. Decreased shrub cover increases nest visibility and consequently nest losses from both visually searching avian nest predators (e.g., Eurasian Magpie [79]) and mammalian predators (e.g., Red Fox (Vulpes vulpes), Pine Marten (Martes foina), free-ranging dogs and cats [16]). These shrub or ground-nesting bird species were also intolerant of impervious areas and disturbance. Therefore, recreational activities with their associated infrastructure (e.g., paths, kiosks, playgrounds) should be kept at a minimum and arranged at the periphery of green spaces.

Urban exploiters, such as the Eurasian Tree and House Sparrows, Feral Pigeon, Northern House Martin and Barn Swallow, are closely associated with built areas, taking advantage of the suitable sites for nesting they offer (i.e., windowsills, wall ledges, roof-tops). However, modern architecture makes buildings unsuitable for nesting for many species [80], and therefore architects must incorporate suitable nesting sites when designing buildings. This is especially urgent for Rovaniemi, were the modern architecture has decreased the nesting possibilities of the House Sparrow, Northern House Martin and Barn Swallow. The closing of balconies with windows has restricted access of martins and swallows to build their nests in wall corners of balconies (J. Jokimäki, unpublished data) and the use of new types of roof tiles with fewer holes or cracks might reduce nest site availability for sparrows [81]. In addition, secondary cavity-nesting species can be helped by erecting artificial nest-boxes $[32,82,83]$.

Several other species that are tolerant of human disturbance and able to exploit anthropogenic food sources use natural substrates to nest, such as trees (Eurasian Magpie, Hooded Crow) or cavities therein (Common Starling, Western Jackdaw) and riverbanks (Black-headed Gull). Furthermore, grasslands and lawns are important foraging sites for species such as the Black-headed Gull and sparrows. These further emphasize the importance of preserving specific elements of the urban landscape, both natural and anthropogenic, for the conservation of bird species, even in urban core areas.

\section{Conclusions}

We analyzed the niche of bird species nesting in the urban core areas of Kavala and Rovaniemi, based on a set of 16 local environmental variables. This analysis involved describing niche characteristics and identifying niche specialization and differences and similarities between the cities. Specialization in niche position was high in both bird communities, with species generally preferring either larger, more vegetated green spaces with lower disturbance, or smaller, more built and disturbed green spaces. Species present in both communities occupied similar niches. This analysis allowed for determining species of conservation priority, also considering their conservation status at the European and national levels. Next, we proposed species-specific conservation actions that would allow for the protection of these species, but also other with similar ecological requirements. In doing so, we also secure the maintenance of diverse urban bird communities.

Several species that were observed in only one green space were not included in the analysis, with some of them being threatened at the European or national levels (Common Swift, Sand Martin, Redwing (Turdus iliacus), Spotted Flycatcher (Muscicapa striata) [70,71]). These species should be also considered a conservation priority and future research should 
explore their ecological requirements and the possibilities for their survival in urban core areas. There is a lack of information on the national conservation status of the bird species observed in Kavala [72]. It is important that threatened species would be classified as conservation priorities upon availability of such information. Future studies should also include other local environmental variables that might have important effects on urban birds, such as nest predation [15,79]), microclimate [31], artificial light at night [84] and the availability of holes in mature and dead standing trees [85]. In addition, although the generally small differences in the measured environmental variables between the cities indicated small differences in ecological conditions that allowed for comparisons, studies including variables of the wider landscape matrix would give further insights. Our study did not contain cities from Central Europe, and therefore the study does not represent an average situation in Europe. For example, some typical Central European parks birds (such as the Wood Pigeon (Columba palumbus), Eurasian Blackcap (Sylvia atricapilla), Eurasian Robin (Erithacus rubecula), Common Chiffchaff (Phylloscopus collybita), and Eurasian Wren (Troglodytes troglodytes) [86-88]) were missing from our samples. We encourage researchers from Central Europe as well as other continents to perform corresponding urban niche studies, also by using other groups than birds.

Supplementary Materials: The following are available online at https://www.mdpi.com/article/10 $.3390 /$ su13116327/s1, Table S1: Common and scientific names, total abundance (sum of individuals in all survey stations) and incidence (number of stations a species was observed) of the bird species recorded in more than $5 \%$ of the survey stations in the green spaces of Kavala (26 species) and Rovaniemi (15 species); Table S2: Environmental variables associated with the urban green spaces of Kavala and Rovaniemi.

Author Contributions: Conceptualization, V.L., J.J. and V.J.K.; investigation, J.J., M.-L.K.-J. and E.V.; methodology, V.L., J.J., M.-L.K.-J. and V.J.K.; software, V.L.; validation, V.L. and J.J.; formal analysis, V.L.; resources, V.L., J.J., M.-L.K.-J., E.V. and V.J.K.; data curation, V.L.; writing-original draft preparation.; V.L.; writing-reviewing and editing, J.J., M.-L.K.-J., E.V. and V.J.K.; visualization, V.L.; supervision, V.L. and J.J.; project administration, V.L. All authors have read and agreed to the published version of the manuscript.

Funding: This research received no external funding.

Institutional Review Board Statement: Ethical review and approval were waived for this study because it did not involve approaching or handling animals.

Informed Consent Statement: Not applicable.

Data Availability Statement: The data presented in this study are available on reasonable request from the corresponding author.

Acknowledgments: The Kavala project was part of the "Planning and managing urban green spaces" postgraduate program of the Department of Forest and Natural Environment Sciences, International Hellenic University. We are grateful to three anonymous reviewers, whose comments and suggestions helped greatly improve the manuscript.

Conflicts of Interest: The authors declare no conflict of interest. V.L. served as a guest editor to the Special Issue "Wildlife Conservation: Managing Resources for a Sustainable World" in which this article has been included. However, he was not in any way involved in the review process, except as an author of the article.

\section{References}

1. Hutchinson, G.E. Concluding remarks. Cold Spring Harb. Symp. Quant. Biol. 1957, 22, 145-159. [CrossRef]

2. Whittaker, R.H.; Levin, S.A.; Root, R.B. Niche, habitat and ecotope. Am. Nat. 1973, 107, 321-338. [CrossRef]

3. Lehmann, S. Growing Biodiverse Urban Futures: Renaturalization and Rewilding as Strategies to Strengthen Urban Resilience. Sustainability 2021, 13, 2932. [CrossRef]

4. Lepczyk, C.A.; Warren, P.S. Urban Bird Ecology and Conservation; University of California Press: Berkeley, CA, USA, 2012.

5. Xu, X.; Xie, Y.; Qi, K.; Luo, Z.; Wang, X. Detecting the response of bird communities and biodiversity to habitat loss and fragmentation due to urbanization. Sci. Total Environ. 2018, 624, 1561-1576. [CrossRef] 
6. Chace, J.F.; Walsh, J.J. Urban effects on native avifauna: A review. Landsc. Urban Plan. 2006, 7, 46-69. [CrossRef]

7. Pellissier, V.; Cohen, M.; Boulay, A.; Clergeau, P. Birds are also sensitive to landscape composition and configuration within the city centre. Landsc. Urban Plan. 2012, 104, 181-188. [CrossRef]

8. Jones, G.A.; Sieving, K.E. Sieving Intercropping sunflower in organic vegetables to augment bird predators of arthropods. Agric. Ecosyst. Environ. 2006, 117, 171-177. [CrossRef]

9. Klein, A.M.; Vaissière, B.E.; Cane, J.H.; Steffan-Dewenter, I.; Cunningham, S.A.; Kremen, C.; Tscharntke, T. Importance of pollinators in changing landscapes for world crops. Proc. R. Soc. B Biol. Sci. 2007, 274, 303-313. [CrossRef]

10. Whelan, C.J.; Sekercioglu, C.H.; Wenny, D.G. Why birds matter: From economic ornithology to ecosystem services. J. Ornithol. 2015, 156, 227-238. [CrossRef]

11. Fuller, R.A.; Irvine, K.N.; Devine-Wright, P.; Warren, P.H.; Gaston, K.J. Psychological benefits of greenspace increase with biodiversity. Biol. Lett. 2007, 3, 390-394. [CrossRef]

12. Cameron, R.W.F.; Brindley, P.; Mears, M.; McEwan, K.; Ferguson, F.; Sheffield, D.; Jorgensen, A.; Riley, J.; Goodrick, J.; Ballard, L.; et al. Where the wild things are! Do urban green spaces with greater avian biodiversity promote more positive emotions in humans? Urban Ecosyst. 2020, 23, 301-317. [CrossRef]

13. Randler, C.; Tryjanowski, P.; Jokimäki, J.; Kaisanlahti-Jokimäki, M.-L.; Staller, N. SARS-CoV2 (COVID-19) Pandemic lockdown influences nature-based recreational activity: The case of birders. Int. J. Environ. Res. Public Health 2020, 17, 7310. [CrossRef]

14. Grimm, N.B.; Faeth, S.H.; Golubiewski, N.E.; Redman, C.L.; Wu, J.G.; Bai, X.M.; Briggs, J.M. Global change and the ecology of cities. Science 2008, 319, 756-760. [CrossRef] [PubMed]

15. Jokimäki, J.; Suhonen, J.; Benedetti, Y.; Diaz, M.; Kaisanlahti-Jokimäki, M.-L.; Morelli, F.; Pérez-Contreras, T.; Rubio, E.; Sprau, P.; Tryjanowski, P.; et al. Land-sharing vs. land-sparing urban development modulate predator-prey interactions in Europe. Ecol. Appl. 2020, 30, 02049. [CrossRef] [PubMed]

16. Loss, S.R.; Will, T.; Marra, P.P. The impact of domestic cats on wildlife of the United States. Nat. Commun. 2013, 4, 1396. [CrossRef] [PubMed]

17. Pollack, L.; Ondrasek, N.R.; Calisi, R. Urban health and ecology: The promise of an avian biomonitoring tool. Curr. Zool. 2017, 63, 205-212. [CrossRef]

18. Jiguet, F.; Sunnen, L.; Prévot, A.-C.; Princé, K. Urban pigeons losing toes due to human activities. Biol. Conserv. 2019, $240,108241$. [CrossRef]

19. MacGregor-Fors, I.; Ortega-Álvarez, R. Fading from the forest: Bird community shifts related to urban park site-specific and landscape traits. Urban For. Urban Green. 2011, 10, 239-246. [CrossRef]

20. Schneider, S.C.; Fischer, J.D.; Miller, J.R. Two-sided edge responses of avian communities in an urban landscape. Urban Ecosyst. 2015, 18, 539-551. [CrossRef]

21. Leveau, L.M.; Leveau, C.M.; Villegas, M.; Cursach, J.A.; Suazo, C.G. Bird communities along urbanization gradients: A comparative analysis among three neo-tropical cities. Ornitol. Neotrop. 2017, 28, 77-87.

22. Tzortzakaki, O.; Kati, V.; Kassara, C.; Tietze, D.T.; Giokas, S. Seasonal patterns of urban bird diversity in a Mediterranean coastal city: The positive role of open green spaces. Urban Ecosyst. 2018, 21, 27-39. [CrossRef]

23. Kontsiotis, V.J.; Valsamidis, E.; Liordos, V. Organization and differentiation of breeding bird communities across a forested to urban landscape. Urban For. Urban Green. 2019, 38, 242-250. [CrossRef]

24. Blair, R.B. Land use and avian species diversity along an urban gradient. Ecol. Appl. 1996, 6, 506-519. [CrossRef]

25. McKinney, M.L. Urbanization as a major cause of biotic homogenization. Biol. Conserv. 2006, 127, 247-260. [CrossRef]

26. Fernández-Juricic, E.; Jokimäki, J. A habitat island approach to conserving birds in urban landscapes-case studies from southern and northern Europe. Biodivers. Conserv. 2001, 10, 2023-2043. [CrossRef]

27. Jokimäki, J.; Suhonen, J. Effects of urbanization on the breeding bird species richness in Finland: A biogeographical comparison. Ornis Fenn. 1993, 70, 71-77.

28. Ives, C.D.; Lentini, P.E.; Threlfall, C.G.; Ikin, K.; Shanahan, D.F.; Garrard, G.E.; Bekessy, S.A.; Fuller, R.A.; Mumaw, L.; Rayner, L.; et al. The importance of cities for threatened species. Glob. Ecol. Biogeogr. 2016, 25, 117-126. [CrossRef]

29. Jokimäki, J.; Suhonen, J.; Kaisanlahti-Jokimäki, M.-L. Urban core areas are important for species conservation: A European-level analysis of breeding bird species. Landsc. Urban Plan. 2018, 178, 73-81. [CrossRef]

30. Miller, J.R.; Hobbs, R.J. Conservation where people live and work. Conserv. Biol. 2002, 16, 330-337. [CrossRef]

31. Gilbert, O.L. The Ecology of Urban Habitats; Chapman and Hall: London, UK, 1989.

32. Jokimäki, J. Occurrence of breeding bird species in urban parks: Effects of park structure and broad-scale variables. Urban Ecosyst. 1999, 3, 21-34. [CrossRef]

33. Carbó-Ramírez, P.; Zuria, I. The value of small urban green spaces for birds in a Mexican city. Landsc. Urban Plan. 2011, 100, 213-222. [CrossRef]

34. Strohbach, M.W.; Lerman, S.B.; Warren, P.S. Are small greening areas enhancing bird diversity? Insights from community-driven greening projects in Boston. Landsc. Urban Plan. 2013, 114, 69-79. [CrossRef]

35. Peris, S.; Montelongo, T. Birds and small urban parks: A study in a high plateau city. Turk. J. Zool. 2014, 38, 316-325. [CrossRef]

36. Jasmani, Z.; Ravn, H.P.; van den Bosch, C.C.K. The influence of small urban parks characteristics on bird diversity: A case study of Petaling Jaya, Malaysia. Urban Ecosyst. 2017, 20, 227-243. [CrossRef] 
37. Amaya-Espinel, J.D.; Hostetler, M.; Henríquez, C.; Bonacic, C. The influence of building density on Neotropical bird communities found in small urban parks. Landsc. Urban Plan. 2019, 190, 103578. [CrossRef]

38. Clergeau, P.; Jokimäki, J.; Savard, J.P.L. Are urban bird communities influenced by the bird diversity of adjacent landscapes? J. Appl. Ecol. 2001, 38, 1122-1134. [CrossRef]

39. Jokimäki, J.; Kaisanlahti-Jokimäki, M.-L. Spatial similarity of urban bird communities: A multiscale approach. J. Biogeogr. 2003, 8, 1183-1193. [CrossRef]

40. Shwartz, A.; Muratet, A.; Simon, L.; Julliard, R. Local and management variables outweigh landscape effects in enhancing the diversity of different taxa in a big metropolis. Biol. Conserv. 2013, 157, 285-292. [CrossRef]

41. Callaghan, C.T.; Major, R.E.; Lyons, M.B.; Martin, J.M.; Kingsford, R.T. The effects of local and landscape habitat attributes on bird diversity in urban greenspaces. Ecosphere 2018, 9, e02347. [CrossRef]

42. Muñoz-Pedreros, A.; González-Urrutia, M.; Encina-Montoya, F.; Norambuena, H.V. Effects of vegetation strata and human disturbance on bird diversity in green areas in a city in southern Chile. Avian Res. 2018, 9, 38. [CrossRef]

43. Titoko, R.; Lowry, J.H.; Osborne, T.; Naikatini, A.; Comely, J.; Riley, R. Relationship of bird richness, abundance and assemblage to the built environment in a small island tropical urban setting: A Suva, Fiji case study. Urban Ecosyst. 2019, 22, 709-719. [CrossRef]

44. Yang, X.; Tan, X.; Chen, C.; Wang, Y. The influence of urban park characteristics on bird diversity in Nanjing, China. Avian Res. 2020, 11, 45. [CrossRef]

45. Da Silva, B.F.; Pena, J.C.; Viana-Junior, A.B.; Vergne, M.; Pizo, M.A. Noise and tree species richness modulate the bird community inhabiting small public urban green spaces of a Neotropical city. Urban Ecosyst. 2021, 24, 71-81. [CrossRef]

46. MacGregor-Fors, I.; Schondube, J.E. Gray vs. green urbanization: Relative importance of urban features for urban bird communities. Basic Appl. Ecol. 2011, 12, 372-381. [CrossRef]

47. Ortega-Álvarez, R.; MacGregor-Fors, I. Living in the big city: Effects of urban land-use on bird community structure, diversity, and composition. Landsc. Urban Plan. 2009, 90, 189-195. [CrossRef]

48. Ferenc, M.; Sedláček, O.; Fuchs, R.; Dinetti, M.; Fraissinet, M.; Storch, D. Are cities different? Patterns of species richness and beta diversity of urban bird communities and regional species assemblages in Europe. Glob. Ecol. Biogeogr. 2014, 23, 479-489. [CrossRef]

49. Jokimäki, J.; Suhonen, J.; Kaisanlahti-Jokimäki, M.-L. Urbanization and species occupancy frequency distribution patterns in core zone areas of European towns. Eur. J. Ecol. 2016, 2, 23-43. [CrossRef]

50. Ibáñez-Álamo, J.D.; Morelli, F.; Benedetti, Y.; Rubio, E.; Jokimäki, J.; Pérez-Contreras, T.; Sprau, P.; Suhonen, J.; Tryjanowski, P.; Kaisanlahti-Jokimäki, M.-L.; et al. Biodiversity within the city: Effects of land sharing and land sparing urban development on avian diversity. Sci. Total Environ. 2020, 707, 135477. [CrossRef] [PubMed]

51. Kark, S.; Iwaniuk, A.; Schalimtzek, A.; Banker, E. Living in the city: Can anyone become an 'Urban Exploiter'? J. Biogeogr. 2007, 34, 638-651. [CrossRef]

52. Croci, S.; Butet, A.; Clergeau, P. Does urbanization filter birds on the basis of their biological traits. Condor 2008, 110, 223-240. [CrossRef]

53. Evans, K.L.; Chaberlain, D.E.; Hatchwell, B.J.; Gregory, R.D.; Gaston, K.J. What makes an urban bird? Glob. Chang. Biol. 2011, 17, 32-44. [CrossRef]

54. Callaghan, C.T.; Major, R.E.; Wilshire, J.H.; Martin, J.M.; Kingsford, R.T.; Cornwell, W.K. Generalists are the most urban-tolerant of birds: A phylogenetically controlled analysis of ecological and life history traits using a novel continuous measure of bird responses to urbanization. Oikos 2019, 128, 845-858. [CrossRef]

55. Callaghan, C.T.; Benedetti, Y.; Wilshire, J.H.; Morelli, F. Avian trait specialization is negatively associated with urban tolerance. Oikos 2020, 129, 1541-1551. [CrossRef]

56. Shugart, H.H.; Patten, B.C. Niche Quantification and the Concept of Niche Pattern. In Systems Analysis and Simulation Ecology; Patten, B.C., Ed.; Academic Press: New York, NY, USA, 1972; pp. 283-327.

57. Gregory, R.D.; Gaston, K.J. Explanations of commonness and rarity in British breeding birds, separating resource use and resource availability. Oikos 2000, 88, 5515-5526. [CrossRef]

58. Shultz, S.; Bradbury, R.; Evans, K.L.; Gregory, R.; Blackburn, T. Brain size and resource specialization predict long-term population trends in British birds. Proc. R. Soc. B 2005, 272, 2305-2311. [CrossRef]

59. Hurlbert, A.H.; White, E.P. Ecological correlates of geographical range occupancy in North American birds. Glob. Ecol. Biogeogr. 2007, 16, 764-773. [CrossRef]

60. Rannap, R.; Lõhmus, A.; Briggs, L. Niche position, but not niche breadth, differs in two coexisting amphibians having contrasting trends in Europe. Divers. Distrib. 2009, 15, 692-700. [CrossRef]

61. Greek Statistical Authority. Population Census 2011. Available online: http://www.statistics.gr/portal/page/portal/ESYE/ PAGE-census2011 (accessed on 5 January 2021).

62. Statistics Finland. Rovaniemi Population, January 2021. Available online: https://pxnet2.stat.fi/PXWeb/pxweb/en/StatFin/ StatFin_vrm_vamuu/statfin_vamuu_pxt_11lj.px/table/tableViewLayout1/ (accessed on 5 January 2021).

63. Bibby, C.; Burgess, N.; Hill, D.; Mustoe, S. Bird Census Techniques, 3rd ed.; Academic Press: London, UK, 2000.

64. Van Heezik, Y.; Seddon, P.J. Accounting for detectability when estimating avian abundance in an urban area. N. Z. J. Ecol. 2012, 36, 391-397. 
65. Sólymos, P.; Lele, S.R.; Bayne, E. Conditional likelihood approach for analyzing single visit abundance survey data in the presence of zero inflation and detection error. Environmetrics 2012, 23, 197-205. [CrossRef]

66. Green, D.M.; Baker, M.G. Urbanization impacts on habitat and bird communities in a Sonoran desert ecosystem. Landsc. Urban Plan. 2003, 36, 225-239. [CrossRef]

67. Donnelly, R.; Marzluff, J.M. Importance of reserve size and landscape context to urban bird conservation. Conserv. Biol. 2004, 18, 733-745. [CrossRef]

68. Litteral, J.; Wu, J. Urban landscape matrix affects avian diversity in remnant vegetation fragments: Evidence from the Phoenix metropolitan region, USA. Urban Ecosyst. 2012, 15, 939-959. [CrossRef]

69. Rico-Silva, J.F.; Cruz-Trujillo, E.J.; Colorado, Z.G.J. Influence of environmental factors on bird diversity in greenspaces in an Amazonian city. Urban Ecosyst. 2021, 24, 365-374. [CrossRef]

70. BirdLife International. European Birds of Conservation Concern: Populations, Trends and National Responsibilities; BirdLife International: Cambridge, UK, 2017.

71. Hyvärinen, E.; Juslén, A.; Kemppainen, E.; Uddström, A.; Liukko, U.-M. The 2019 Red List of Finnish Species; Ministry of the Environment; Finnish Environment Institute: Helsinki, Finland, 2019.

72. Legakis, A.; Maragou, P. The Red Data Book of Threatened Animals of Greece; Hellenic Zoological Society: Athens, Greece, 2009.

73. Dolédec, S.; Chessel, D.; Gimaret-Carpentier, C. Niche separation in community analysis: A new method. Ecology 2000, 81, 2914-2927. [CrossRef]

74. Dray, S.; Dufour, A.B. The ade4 Package: Implementing the Duality Diagram for Ecologists. J. Stat. Softw. 2007, 22, 1-20. [CrossRef]

75. Harrell, F.E., Jr.; Dupont, C. Hmisc: Harrell Miscellaneous-R Package Version 4.4-1. 2020. Available online: https:/ /CRAN.Rproject.org $/$ package $=$ Hmisc (accessed on 5 January 2021).

76. R Core Team. R: A Language and Environment for Statistical Computing; R Foundation for Statistical Computing: Vienna, Austria, 2020. Available online: https:/ / www.R-project.org/ (accessed on 5 January 2021).

77. Keller, V.; Herrando, S.; Voříšek, P.; Franch, M.; Kipson, M.; Milanesi, P.; Martí, D.; Anton, M.; Klvaňová, A.; Kalyakin, M.V.; et al. European Breeding Bird Atlas 2: Distribution, Abundance and Change; European Bird Census Council: Beek, The Netherlands; Lynx Edicions: Barcelona, Spain, 2020.

78. Ahvenainen, J. Rovaniemen Historia II 1632-1960; Kirjapaino Oy: Kuopio, Finland, 1970.

79. Jokimäki, J.; Huhta, E. Artificial nest predation and abundance of birds along an urban gradient. Condor 2000, 102, 838-847. [CrossRef]

80. Murgui, E. Breeding habitat selection in the House martin Delichon urbica in the city of Valencia (Spain). Acta Ornithol. 2002, 37, 75-83. [CrossRef]

81. Moudra, L.; Zasadil, P.; Moudry, V.; Salek, M. What makes new housing development unsuitable for house sparrows (Passer domesticus)? Landsc. Urban Plan. 2018, 169, 124-130. [CrossRef]

82. Gaston, K.J.; Warren, P.H.; Thompson, K.; Smith, R.M. Urban domestic gardens (IV): The extent of the resource and its associated features. Biodivers. Conserv. 2005, 14, 3327-3349. [CrossRef]

83. Balaji, S. Artificial nest box for house sparrow: An apt method to save the dwindling species in an urban environment. Int. J. Biodivers. Conserv. 2014, 6, 194-198. [CrossRef]

84. Ciach, M.; Fröhlich, A. Habitat type, food resources, noise and light pollution explain the species composition, abundance and stability of a winter bird assemblage in an urban environment. Urban Ecosyst. 2017, 20, 547-559. [CrossRef]

85. Murgui, E. Factors influencing the bird community of urban wooded streets along an annual cycle. Ornis Fenn. $2007,84,66-77$.

86. Ferenc, M.; Sedláček, O.; Fuchs, R. How to improve urban greenspace for woodland birds: Site and local-scale determinants of bird species richness. Urban Ecosyst. 2014, 17, 625-640. [CrossRef]

87. Tryjanowski, P.; Morelli, F.; Mikula, P.; Krištín, A.; Indykiewicz, P.; Grzywaczewski, G.; Kronenberg, J.; Jerzak, L. Bird diversity in urban green space: A large-scale analysis of differences between parks and cemeteries in Central Europe. Urban For. Urban Green. 2017, 27, 264-271. [CrossRef]

88. Witt, K.; Mitschke, A.; Luniak, M. A comparison of common breeding bird populations in Hamburg, Berlin and Warsaw. Acta Ornithol. 2005, 40, 139-146. [CrossRef] 